\title{
PENGEMBANGAN E-MODULE BERCIRIKAN ETNOMATEMATIKA PADA MATERI BANGUN RUANG SISI DATAR
}

\section{DEVELOPMENT OF E-MODULE ESTABLISHING ETHNOMATHEMATICS IN BUILDING ROAD SIDE MATERIAL}

\author{
Intan Kurniasari, Rosida Rakhmawati $\mathbf{M}^{2}$, Jamal Fakhri ${ }^{3}$ \\ 1,2,3 Program Studi Pendidikan Matematika, FTK UIN Raden Intan Lampung \\ E-mail : intankurniasari01@gmail.com
}

Diterima: 17 September 2018. Disetujui: 05 Oktober 2018. Dipublikasikan: 29 November 2018

\begin{abstract}
This research is included in research and development that aims to produce e-module characterized by ethnomathematics on the matter of building a flat side space. Making this e-module using exe-learnig applications. This research use 4-D development model that is Define, Design, Development and Disseminate. The results obtained from the list of experts with an average score of 3,88 and media experts with an average score of 3,90 so that the product has met the eligibility criteria, while the teacher response to get an average score of 3,08 with interesting criteria and response learnes with an average score of 3,52 are included in very interesting criteria. So it can be concluded that the developed e-modue declared eligible for use.

Abstrak: Penelitian ini termasuk dalam penelitian dan pengembangan yang bertujuan untuk menghasilkan e-module yang bercirikan etnomatematika pada materi bangun ruang sisi datar. Pembuatan E-module ini menggunakan aplikasi exe-learning. Penelitian ini menggunakan model pengembangan 4-D yaitu Define, Design, Development dan Disseminate. Hasil penelitian yang diperoleh dari penilaian ahli materi dengan skor rata-rata 3,88 dan ahli media dengan skor rata-rata 3,90 sehingga produk dinyatakan telah memenuhi kriteria kelayakan, sedangkan untuk respon pendidik mendapatkan skor rata-rata 3,08 dengan kriteria menarik dan respon peserta didik dengan skor rata-rata 3,52 termasuk dalam kriteria sangat menarik. Sehingga dapat disimpulkan bahwa e-module yang dikembangkan dinyatakan layak untuk digunakan.
\end{abstract}

(C) 2018 Unit Riset dan Publikasi Ilmiah FTK UIN Raden Intan Lampung

Kata kunci: Bangun Ruang, E-module, Etnomatematika

\section{PENDAHULUAN}

Pembelajaran matematika dapat meningkatkan kemampuan matematis melalui pembelajaran yang berkaitan dengan budaya yaitu etnomatematika. Menurut Ubiratan D'Ambrosio etnomatematika adalah untuk menggambarkan praktik matematika di daam suatu budaya (Daniel Clark Orey, 2010), jadi etnomatematika adalah matematika yang dapat dikaitkan dengan unsur budaya. Permasalahan yang dialami peserta didik dalam kesulitan belajar matematika sebenarnya terletak pada penggunaan media pembelajaran atau bahan ajar yang digunakan pendidik dalam kegiatan pembelajaran, jika pendidik lebih maksimal dalam memanfaatkan media pembelajaran pendidik lebih mudah dalam menyampaikan materi dan peserta didik lebih mudah menangkap materi yang dijelaskan oleh pendidik.

Berdasarkan hasil pra-penelitian dengan menyebarkan angket kepada peserta didik, diperoleh hasil bahwa peserta didik masih merasa kesulitan dalam mempelajari materi bangun ruang sisi datar, dapat dilihat dalam diagram berikut : 


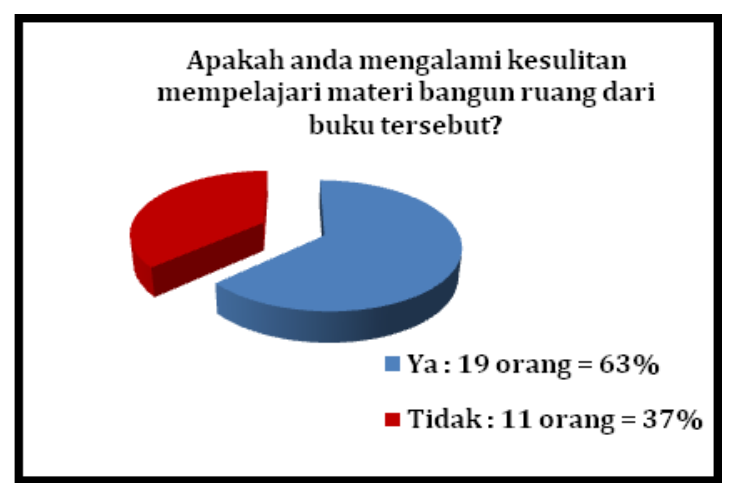

Gambar 1. Kesulitan belajar peserta didik

Gambar 1 menampilkan bahwa peserta didik mengalami kesulitan memahami materi bangun ruang jika hanya mempelajari materi bangun ruang hanya dengan menggunakan buku cetak saja. Sebanyak 19 peserta didik atau setara dengan $63 \%$ peserta didikmengaku bahwa mereka mengalami kesulitan.

Selanjutnya diperoleh bahwa peserta didik menginginkan sumber pembelajaran alternatif yang menarik, dapat dilihat dalam diagram berikut :

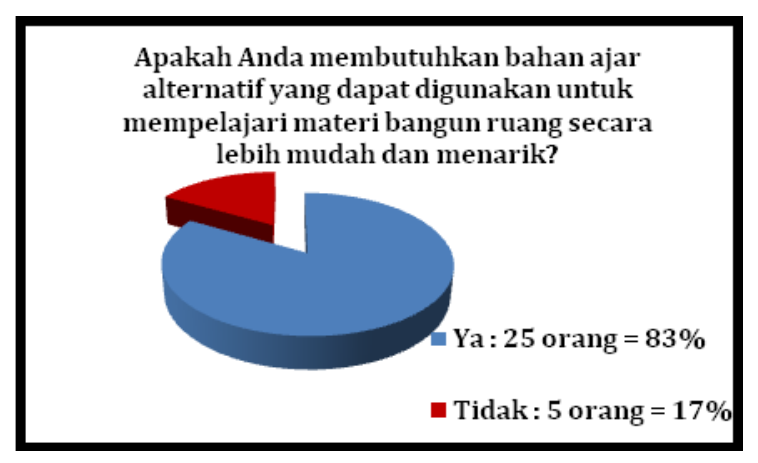

Gambar 2. Kebutuhan bahan ajar alternatif peserta didik pada materi Bangun Ruang

Gambar 2 adalah tampilan hasil kuesioner analisis kebutuhan peserta didik tentang kebutuhan sumber belajar alternatif. Berdasarkan pertanyaan yang disajikan pada kuesioner sebanyak 25 dari 30 peserta didik atau setara dengan $83 \%$ menyatakan bahwa mereka membutuhkan sumber belajar alternatif dengan alasan jika menggunakan sumber belajar alternatif lebih menarik perhatian peserta didik sehingga materi yang dipelajari lebih mudah dipahami.

Kemudian pertanyaan berikutnya diperoleh hasil bahwa peserta didik kerap mencari sumber belajar alternatif sebagai sumber belajar mandiri, dapat dilihat dalam diagram berikut :

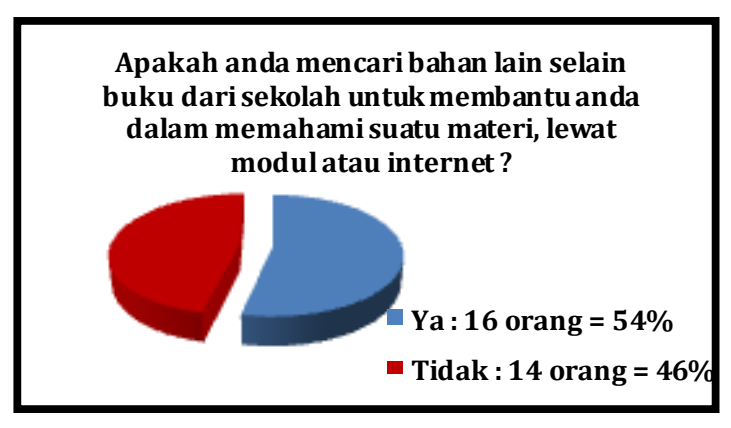

Gambar 3. Diagram referensi belajar peserta didik

Gambar 3 menjelaskan bahwa peserta didik juga mencari referensi lain sebagai sumber belajarnya salah satunya yaitu internet. Sebanyak 16 peserta didik atau setara dengan 54\% peserta didik mencari sumber belajar melalui internet untuk memahami materi yang belum ia pahami dari buku yang mereka pelajari. Berdasarkan hasil kuesioner, dapat dilihat bahwa peserta didik sudah mampu menggunakan teknologi informasi.

Berdasarkan hasil pra penelitian, salah satu cara untuk mengurangi kesulitan belajar peserta didik adalah dengan membuat media pembelajaran interaktif. E-module termasuk dalam media interaktif, e-module adalah seperangkat media pengajaran digital atau non cetak yang disusun secara sistematis yang digunakan untuk keperluan belajar mandiri, sehingga menuntut siswa untuk belajar memecahkan masalah dengan caranya sendiri (2017). Aplikasi yang dapat digunakan dalam proses pembuatan e-module diantaranya adalah Exelearning. Pembelajaran menggunakan Exe-Learning ini lebih memudahkan 
pendidik untuk menyampaikan materi. Pembelajaran metematika menggunakan media (bahan ajar) interaktif, akan lebih menarik dan efektif (Suarsana, 2013).

Penelitian ini mengacu pada beberapa penelitian terdahulu yaitu yang dilakukan oleh Iin Rahmatul Ula yaitu berupa pengembangan e-modul berbasis LCDS (Ula \& Fadila, 2018), penelitian ini sama dengan penelitian yang akan peneliti lakukan yaitu dengan mengembangkan $e$ module dan perbedaannya adalah terletak pada aplikasi yang digunakan peneliti yaitu exe-learning dan peneliti mengaitkan materi dengan eetnomatematika. Berikutnya penelitian yang dilakukan oleh Alif Satria Egar Santosa yaitu pengembangan e-modul berbasis model pembelajaran Problem Based Learning ( et al., 2017), penelitian ini juga mengembangkan e-module, namun penelitian yang akan dilaksanakan tidak menggunakan model pembelajaran problem solving melainkan menggunakan pendekatan etnomatematika. Selanjutnya penelitian yang dilakukan oleh Nyoman Sugihartini yaitu pengembangan e-modul mata kuliah strategi pembelajaran, penelitian ini juga mengembangkan dan menghasilkan produk, tapi perbedaan dengan penelitian yang akan dilakukan penelitian terdahulu menggunakan pendekatan project based learning sedangkan penelitian yang akan dilakukan menggunakan pendekatan etnomatematika (Sugihartini \& Jayanta, 2017). Berdasarkan penelitian terdahulu dapat disimpulkan e-module dapat dikembangkan dengan berbagai pendekatan sebagai salah satu sumber belajar interaktif peserta didik.

Selanjutnya penelitian yang dilakukan Elma Purnama Aini berupa Handout matematika berbantuan etnomatematika berbasis budaya lokal (2018a), penelitian ini sama dengan penelitian yang akan dilakukan peneliti yaitu menggunakan etnomatematika sebagai pendekatannya, namun terdapat perbedaan yaitu penelitian ini menghasilkan produk berupa handout matematika sedangkan penelitian yang akan dilakukan akan dihasilkan produk berupa e-module. Penelitian selanjutnya dilakukan oleh Wiwin Sumiyati yaitu penggunaan media pembelajaran geometri berbasis etnomatematika (2018b) penelitian ini mencari tahu tentang pengaruh penggunaan media belajar berbasis etnomatematika, perbedaan dari penelitian yang akan dilakukan adalah penelitian ini tidak mengembangkan produk tetapi membedakan hasil belajar peserta didik yang menggunakan dengan yang tidak menggunakan media belajar berbasis etnomatematika. Selanjutnya adalah penelitan yang dilakukakan Rosida Rakhmawati $M$ yang meneliti tentang aktifitas matematika berbasis budaya pada masyarakat Lampung (Rakhmawati, 2016) penelitian ini mendeskripsikan hasil eksplorasi matematika masyarakat lampung, perbedaan dengan penelitian yang akan dilakukan adalah peneliti mengaitkan materi bangun ruang dengan budaya lokal salah satunya yaitu rumah adat sedangkan penelitian terdahulu melihat bentuk geometri pada motif kain tapis dan permainan tradisional. Selanjutnya penelitian yang dilakukan oleh I Wayan Eka Mahendra yaitu Project Based Leraning bermuatan etnomatematika dalam belajar matematika (Mahendra, 2017) penelitian ini bertujuan untuk mengetahui perbedaan hasil belajar peserta didik yang mengikuti dengan yang tidak mengikuti model pembelajaran project based learning bermuatan etnomatematika. Perbedaan dengang penelitian yang akan dilakukan adalah penelitian terdahulu tidak mengembangkan bahan ajar melainkan menerapkan model pembeljaran yang bermuatan etnomatematika. Berdasarkan penelitian terdahulu dapat disimpulkan bahwa matematika dapat dikaitkan dengan nilai-nilai budaya sehingga dpat menambah wawasan peserta didik untuk 
mendapatkan konsep matematika sekaligus budaya lokal.

Kemudian penelitian yang menggunakan aplikasi exe-learning sebagai media untuk penelitian dilakukan oleh Iis Siti Jahro dan Dimas Ridho yaitu Penerapan Model Problem Based Learning Menggunakan Media Exe Learning untuk Meningkatkan Hasil Belajar dan Kerjasama Siswa pada Materi Hidrokarbon (2015) penelitian ini mencari pengaruh hasil belajar peserta didik dalam menerapkan model PBL dengan menggunakan media exe-learning dan tanpa menggunakan media exe-learning, penelitian ini sama-sama mengunakan exe-learning sebagai program pembuatan media interaktif namun perbedaan terletak pada materinya peneliti akan menggunkan materi bangun ruang sisi datar sedangkan penelitian terdahulu menggunakan materi hidrokarbon. Selanjutnya penelitian yang dilakukan Ida Safitri yaitu pengembangan e-module dengan pendekatan matematika berbantuan flipbook maker pada materi bangun ruang sisi datar (Safitri, 2017) penelitian ini mempunyai kesamaan dengan penelitian tang akan dilakukan yaitu mengembangkan e-module dan menggunakan materi bangun ruang, perbedaannya adalah penelitian terdahulu tidak menggunakan pendekatan etnomatematika dan tidak menggunakan exe-learning sebagai program pembuat $e$ module.

Berdasarkan penelitian terdahulu, peneliti tertarik untuk mengembangkan produk berupa e-module berbasis exelearning pada materi bangun ruang sisi datar. Penelitian ini mempunyai perbedaan atau keterbaruan dengan penelitian sebelumnya yaitu tidak hanya mengembangkan berupa e-module saja tetapi di dalam e-module tersebut materi bangun ruang ini akan dikaitkan dengan etnomatematika yaitu budaya lokal, dengan tujuan peserta didik agar lebih memahami materi bangun ruang yang ada kaitannya dengan budaya lokal.

\section{METODE PENELITIAN}

Jenis penelitian yang digunakan pada penelitian ini adalah penelitian dan pengembangan (Research and Development). Penelitian dan pengembangan adalah proses yang digunakan untuk mengembangkan dan memvalidasi produk. Penelitian ini menggunakan model pengembangan 4-D yaitu 1) Define, 2) Design, 3) Development , 4) Disseminate (2015) (Widayanti \& Yuberti, 2018). Teknik pengumpulan data yang digunakan adalah untuk mengetahui respon pendidik dan peserta didik terhadap e-module bercirikan etnomatematika dengan menggunakan kuesioner, wawancara dan dokumentasi.

Instrumen yang digunakan pada pengembangan e-module berupa lembar validasi ahli, lembar respon pendidik dan peserta didik yang bertujuan untuk mengetahui kelayakan e-module. Instrumen dalam pengumpulan data menggunakan skala likert dalam penilaian oleh validator yaitu skor 4 dengan kriteria sangat baik, skor 3 dengn kriteria baik, skor 2 dengan kriteria kurang baik dan skor 1 dengan kriteria sangat kurang baik, dapat dilihat pada Tabel 1. Penilaian rata-rata skor penilaian dihitung menggunakan rumus berikut : (Lucky C F, Sulur dan Yudyanto, 2014)

$$
\bar{x}=\frac{\sum_{i=1}^{n} x_{i}}{n}
$$

Keterangan :

$\bar{x}=$ Nilai rata - rata akhir

$x_{i}=$ jumlah skor jawaban penilaan

$n=$ jumlah validator 
Skor penilaian validasi dapat dilihat pada tabel berikut :

Tabel 1. Skor Penilaian Validator

\begin{tabular}{cc}
\hline Kategori & Skor \\
\hline Sangat baik & 4 \\
Baik & 3 \\
Kurang baik & 2 \\
Sangat kurang baik & 1 \\
\hline
\end{tabular}

Kemudian untuk melihat kriteria kelayakan e-module menggunakan tabel skala likert sebagai berikut :

Tabel 2. Kriteria Validasi (dimodifikasi)

\begin{tabular}{cc}
\multicolumn{1}{c}{ Skor Kualitas } & Kriteria \\
\hline $3,26<\bar{x} \leq 4,00$ & Valid \\
$2,51<\bar{x} \leq 3,26$ & Cukup valid \\
$1,76<\bar{x} \leq 2,51$ & Kurang valid \\
$1,00<\bar{x} \leq 1,76$ & Tidak valid \\
\hline
\end{tabular}

Sedangkan untuk menganalisis data respon pendidik dan peserta didik dengan menyebarkan angket dan skor penilaian dapat dilihat pada tabel berikut :

Tabel 3. Skor penilaian uji coba

\begin{tabular}{cc}
\hline Kategori & Skor \\
\hline Sangat menarik & 4 \\
Menarik & 3 \\
Kurang menarik & 2 \\
Sangat kurang menarik & 1 \\
\hline
\end{tabular}

Kemudian setelah menghitung skor rata-rata perolehan skor respon pendidik dan peserta didik untuk melihat kriteria kemenarikan e-module dapat dilihat pada tabel berikut :

Tabel 4. Kriteria uji coba (dimodifikasi)

\begin{tabular}{lc}
\hline Skor Kualitas & Kriteria \\
\hline $3,26<\bar{x} \leq 4,00$ & Sangat Menarik \\
$2,51<\bar{x} \leq 3,26$ & Menarik \\
$1,76<\bar{x} \leq 2,51$ & Kurang Menarik \\
$1,00<\bar{x} \leq 1_{s}, 76$ & Sangat Tidak Menarik \\
\hline
\end{tabular}

Pengembangan produk ini akan berakhir apabila skor penilaian rata-rata dari produk telah memenuhi kriteria kelayakan pada penilaian validator dan kriteria sangat menarik atau menarik pada penilaian respon pendidik dan peserta didik.

\section{HASIL DAN PEMBAHASAN}

Pengembangan ini menghasilkan produk berupa e-module bercirikan etnomatematika pada materi bangun ruang sisi datar yang menggunakan model pengembangan 4-D (Define, Design, Development dan Disseminate). Manfaat dari e-module ini dapat dijadikan bahan ajar bagi pendidik dan dapat dijadikan sumber belajar mandiri peserta didik.

Langkah pertama adalah Define (pendefinisian) yaitu tahap untuk mencari data awal melalui wawancara kepada guru matematika dan menyebarkan kuesioner kepada peserta didik untuk mengetahui kebutuhan peserta didik serta potensi yang ada di sekolah. Berdasarkan tahap pendefinisian diperoleh bahwa pendidik masih menggunakan metode konvensional dalam kegiatan belajar mengajar dan hanya menggunakan buku cetak sebagai bahan ajar.

Tahap berikutnya yaitu design (perencanaan) dengan merencanakan produk yang akan dikembangkan sesuai kebutuhan peserta didik berupa e-module bercirikan etnomatematika yang pembuatannya dengan menggunakan aplikasi exe-learning dan materi yang dipilih adalah bangun ruang sisi datar. Tahap perancangan ini adalah dengan mengumpulkan bahan-bahan yang akan dimasukkan dalam e-module seperti video dan gambar yang sesuai dengan materi bangun ruang dan budaya lokal, serta animasi.

Selanjutnya tahap development (pengembangan) yaitu tahap penyusunan $e$-module, setelah e-module selesai disusun selanjutnya divalidasi oleh validator hingga e-module dinyatakan valid dan layak untuk digunakan, setelah itu produk diujicobakan kepada pendidik dan peserta didik untuk melihat kemenarikan produk yang dikembangkan. Berikut hasil validasi ahli materi tahap ke1 dan tahap ke-2 : 
Tabel 5. Hasil Validasi Ahli Materi

\begin{tabular}{ccc}
\hline Tahap & Skor Rata-Rata & Kriteria \\
\hline 1 & 2,63 & Cukup valid \\
2 & 3,78 & Valid \\
\hline
\end{tabular}

Berdasarkan tabel 5 hasil penilaian ahli materi pada tahap ke-1 diperoleh skor rata-rata sebesar 2,63 dengan kriteria cukup valid. Hal ini dikarenakan menurut ahli materi, materi bangun ruang sisi datar dalam e-module belum mencakup semua bahasan materi dan masih belum banyak mengaitkan etnomatematika. Kemudian peneliti melakukan revisi terhadap $e$ module dan kembali melakukan validasi kepada ahli materi. Penilaian tahap ke-2 memperoleh skor rata-rata sebesar 3,78 dengan kriteria valid. Menurut ahli materi e-module telah mencakup keseluruhan materi dan tidak perlu dilakukan revisi. Berikut adalah tampilan produk sebelum dan setelah direvisi :

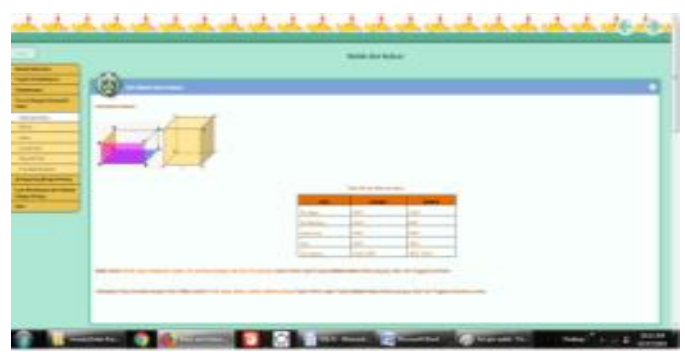

Gambar 4. Sebelum revisi

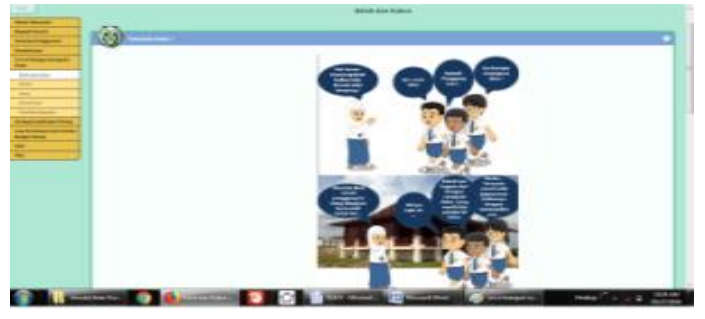

Gambar 5. Setelah revisi

Sehingga dapat ditarik kesimpulan bahwa e-module bercirikan etnomatematika pada materi bangun ruang telah layak digunakan pendidik dan peserta didik sebagai sumber belajar.

Selanjutnya validasi ahli media, validasi ahli media juga melalui dua tahap validasi. Berikut hasil skor penilaian validasi ahli media tahap 1 dan tahap 2 :

Tabel 6. Hasil Validasi Ahli Media

\begin{tabular}{ccc} 
Tahap & Skor Rata-Rata & Kriteria \\
\hline 1 & 2,97 & Cukup valid \\
2 & 3,90 & Valid \\
\hline
\end{tabular}

Berdasarkan tabel 6 hasil penilaian ahli media pada tahap ke-1 diperoleh skor rata-rata sebesar 2,97 dengan kriteria cukup valid. Hal in dikarenakan menurut ahli media e-module ini belum menarik karena masih belum ada perbedaan antar modul cetak dengan modul elektronik, ahli media menyarankan agar e-module lebih memperbanyak gambar, video dan animasi agar pembaca lebih tertarik untuk mempelajari isi materi. Kemudian peneli merevisi e-module sesuai dengan saran yang diberikan oleh ahli media. Penilaian tahap ke-2 memperoleh skor rata-rata sebesar 3,90 dengan kriteria valid. Menurut ahli media, e-module sudah menarik dan telah dinyatakan layak digunakan maka tidak perlu dilakukan revisi kembali. Berikut adalah tampilan produk sebelum dan setelah direvisi :

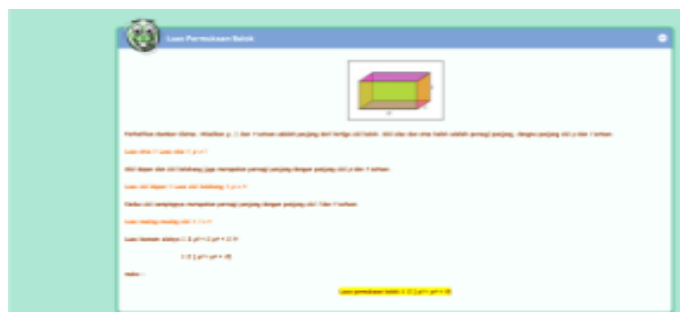

Gambar 6. Sebelum revisi

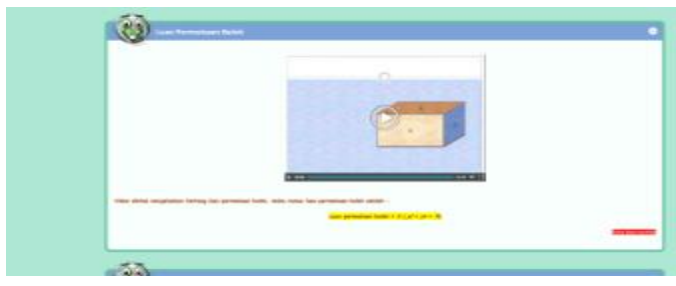

Gambar 7. Setelah revisi 
Setelah melakukan validasi dan produk telah dinyatakan valid dan layak digunakan, langkah selanjutnya adalah melakukan uji coba produk kepada pendidik dan peserta didik. Uji coba produk kepada pendidik dilakukan dengan memberikan produk dan angket kepada dua guru matematika untuk menilai produk. Berdasarkan uji coba respon pendidik diperoleh skor rata-rata penilaian produk sebesar 3,08 dengan kriteria menarik. Hal ini dikarenakan pendidik menyatakan bahwa e-module dapat mempermudah peserta didik dalam menyampaikan materi dan dapat menarik perhatian peserta didik. Selanjutnya uji coba respon peserta didik melalui dua tahap yaitu uji kelompok kecil dan kelompok besar. Peneliti mengambil 10 peserta didik untuk uji kelompok kecil dan 30 peserta didik untuk uji kelompok besar.

Hasil uji respon peserta didik pada uji kelompok kecil diperoleh hasil skor rata-rata sebesar 3,52 dengan criteria sangat menarik. Berdasarkan hasil uji coba kelompok kecil yang telah memenuhi kriteria sangat menarik, maka peneliti tidak perlu melakukan revisi dan melakukan uji kelompok besar. Hasil uji kelompok besar memperoleh skor ratarata sebesar 3,34 dengan kriteria sangat menarik. Berdasarkan hasil uji kelompok kecil maupun kelompok besar dapat dilihat bahwa e-module termasuk dalam kategori menarik, hal tersebut dikarenakan menurut peserta didik emodule yang peneliti kembangkan menarik perhatian mereka, dan mereka meraskan bahwa lebih antusias dalam mempelajari materi bangun ruang.

Berdasarkan uji coba respon pendidik dan peserta didik maka produk yang dikembangkan telah memenuhi criteria kemenarikan dan produk tidak perlu direvisi kembali.

Tahap yang terakhir yaitu Disseminate (penyebaran) dengan menyebarkan produk yang telah melalui tahap pengembangan dan telah dinyatakan layak untuk digunakan. Peneliti menyebarkan produk ke laboratorium komputer di sekolah dan online melalui web.

Berdasarkan pemaparan hasil dari penelitian ini dapat disimpulkan bahwa $e$ module berbasis exe-learning yang bercirikan etnomatematika ini mendapatkan respon positif dari pendidik dan peserta didik, sehingga e-module yang dikembangkan dapat digunakan sebagai sumber belajar interaktif peserta didik. Hasil penelitian ini terdapat kesamaan dengan penelitian terdahulu yaitu e-module yang dikembangkan mendapatkan respon positif dari peserta didik sehingga e-module layak digunakan sebagai sumber belajar mandiri. Terbukti dari hasil penelitian penggunaan $e$-module yang menggunakan aplikasi exe-learning berorientasi pemecahan masalah, menunjukkan bahwa keterampilan berpikir kritis mahasiswa mengalami peningkatan dan tanggapan terhadap $e$ module sangat positif. Hal ini dapat dilihat dari hasil penelitian tersebut yaitu e-module yang disusun berkualitas baik, penggunaan e-module dapat meningkatkan keterampilan berpikir kritis mahasiswa dari rata-rata 27,6 pada siklus I menjadi 31,4 pada siklus II dan tanggapan mahasiswa terhadap penggunaan e-module adalah sangat positif (Suarsana, 2013).

Perbedaan dengan penelitian sebelumnya adalah peneliti menggunakan exe-learning pada pembuatan e-module mengaitkan materi bangun ruang dengan budaya lokal yaitu dengan memberikan informasi mengenai budaya lokal yang mempunyai unsur matematika. Hasil dari angket uji respon peserta didik mendapatkan skor 3,52 pada uji kelompok kecil dan skor 3,34 pada uji kelompok besar dengan kriteria "sangat menarik". Berdasarkan pembahasan di atas dapat disimpulkan bahwa e-modulep berbasis exe-learning bercirikan etnomatematika 
sangat menarik dan layak untuk digunakan.

\section{SIMPULAN DAN SARAN}

Berdasarkan hasil penelitian diperoleh kesimpulan bahwa e-module bercirikan etnomatematika dengan menggunakan aplikasi exe-learning memperoleh respon positif dari pendidik dan peserta didik ditunjukkan dari data hasil angket respon pendidik dengan skor rata-rata yang diperoleh 3,08 yang termasuk dalam kriteria "menarik" dan respon peserta didik dengan skor rata -rata yang diperoleh 3,52 pada uji kelompok kecil dan 3,34 pada uji kelompok besar yang termasuk dalam kriteria "sangat menarik".

$$
\text { E-module bercirikan }
$$

etnomatematika ini hanya sampai pada tahap penyebaran, sehingga peneliti menyarankan untuk dilakukan tahap lanjutan sampai ke tahap implementasi agar dapat mngetahui keefektifan $e$ module.

\section{DAFTAR PUSTAKA}

Alif Satria Egar Santosa, Gede Saindra Santyadiputra, \& Dewa Gede Hendra Divayana. (2017). Pengembangan E-modul Berbasis Model Pembelajaran Problem Based Learning Pada Mata Pelajaran Administrasi Jaringan Kelas XII Teknik Komputer dan Jaringan di SMK TI Bali Global Singaraja, 6(1).

Elma Purnama Aini, Komarudin, \& Ruhban Masykur. (2018). Handout Matematika berbantuan Etnomatematika Berbasis Budaya Lokal, 1(1), 73-79.

Iis Siti Harjo, \& Dimas Ridho. (2015). Penerapan Model Problem Based Learning Menggunakan Media Exe Learning untuk Meningkatkan Hail Belajar dan Kerjasama Siswa
Pada Materi Hidrokarbon, 7(3), 80-86.

Mahendra, I. W. E. (2017). Project Based Learning Bermuatan Etnomatematika Dalam Pembelajar Matematika. Jpi (Jurnal Pendidikan Indonesia), $6(1)$.

Milton Rosa, \& Daniel Clark Orey. (2010). Ethnomathematics: the cultural aspects of mathematics, 4(2), 35.

Rosida Rakhmawati M. (2016). Aktivitas Matematika Berbasis Budaya pada Masyarakat Lampung, 7(2), 221230.

Safitri, I. (2017). Pengembangan EModule Dengan Pendekatan Pembelajaran Matematika Realistik Berbantuan Flipbook Maker Pada Materi Bangun Ruang Sisi Datar Kelas Viii Smp. Aksioma, 6(2), 1.

Suarsana, I. M. (2013). Pengembangan EModul Berorientasi Pemecahan Masalah Untuk Meningkatkan Keterampilan Berpikir Kritis Mahasiswa. JPI (Jurnal Pendidikan Indonesia), 2(2).

Sugihartini, N., \& Jayanta, N. L. (2017). Pengembangan E-Modul Mata Kuliah Strategi Pembelajaran. Jurnal Pendidikan Teknologi dan Kejuruan, 14(2).

Sugiyono. (2015). Metode Penelitian dan Pengembangan (Research and Development). Bandung: Alfabeta.

Ula, I. R., \& Fadila, A. (2018). Pengembangan E-Modul Berbasis Learning Content Development System Pokok Bahasan Pola Bilangan SMP, 1(2), 201-207.

Widayanti, W., \& Yuberti, Y. (2018).

Pengembangan Alat Praktikum

Sederhana sebagai Media Praktikum Mahasiswa. JIPFRI (Jurnal Inovasi Pendidikan Fisika Dan Riset Ilmiah), 2(1), 21-27. 
Wiwin Sumiyati, Netriwati, \& Rosida

Rakhmawati M. (2018).

Penggunaan Media Pembelajaran

Geomeetri Berbasis

Etnomatematika, 1(1), 15-21. 